\title{
Possibilities for Intercultural Cooperation Development in Cultural Centres
}

\author{
Virginija Jurènienè \\ Vilnius University, Kaunas, Lithuania
}

\begin{abstract}
Intercultural cooperation takes place within a country and among countries. The level of cooperation is macro, meso and micro, depending on the nature and strength of the organisation. Intercultural cooperation is carried out by various cultural and educational institutions. Cultural centre is one of very few cultural organisations, having few analogues in other countries, cherishing, preserving and supporting ethnical culture and creating state image through intercultural cooperation. Thus, a scientific issue examined in the article is intercultural cooperation and communication in the activities of various cultural centres, analysing the macro, meso and micro levels. The quantitative research, conducted in eight cultural centres operating in the border areas of Lithuania, Belarus and the Kaliningrad Region (Russia), i.e. Kybartai, Pagėgiai, Švencionys, Lazdijai, Pelesa, Rimdžiūnai, Sovetskas and Gusev, helped to identify the intercultural levels of these cultural centres and their communities. Estimating different circumstances of the activity of Lithuanian cultural centres and cultural organisations operating in the Kaliningrad and Belarus border areas (Lithuanian cultural centres/ Lithuanian communities), a comparative analysis revealed the key features of cooperation between the community and the cultural centres/Lithuanian organisations. The study also analysed the patterns of intercultural cooperation.
\end{abstract}

Keywords: cooperation, ethnic culture, cultural heritage, cultural centres

\section{Introduction}

The current post-modern society is closely related to the globalisation process, one of the main characteristics of which is the movement of finances, technologies, knowledge, human resources, ideas, cultural values, etc., despite of national borders. The consequence of this movement and other characteristics of globalisation is the formation of multicultural societies. Now it is not a surprise to see people of different cultures living nearby, intercultural marriages, etc.

The European Union is characterised by multiple cultures, but at the same time national cultures are also being nourished. The decisions of the UNESCO and the Council of Europe encourage the retention of national identity. Each nation has its unique national culture that is an invaluable property. An important task of the EU countries and nations is to co-ordinate the influence of globalisation and the culture of consumption upon national culture without annihilating it.

But cultures are always changing and they are related to the symbolic dimension of life, the meaning and

Virginija Jurènienė, Dr., Prof., Department of Philosophy and Culture Studies, Vilnius University, Kaunas Faculty of Humanities.

Correspondence concerning this article should be addressed to Muitines str.8, LT-44280 Kaunas, Lithuania. E-mail: Virginija.jureniene@khf.vu.lt. 
the identity are created from them. Cultural differences are clearly demonstrated through conflicts and may become the reason for them to emerge. Cultural differences appear both in national and international countries. These differences are more distinct in the EU integration processes.

The Lithuanian state puts a lot of efforts to retain ethnic culture and strengthen it. The Seimas of the Republic of Lithuania has passed laws. The preamble of the law on The Principles of State Protection of Ethnic Culture declares that Seimas of the Republic of Lithuania, cognisant of the fact that ethnic culture constitutes the essence of national existence, survival and strength; stating that the various forms of Lithuanian ethnic culture and particularly its living traditions are in obvious danger of extinction; acknowledging that only a nation which relies upon its culture can support the civic maturity of the members of its society, participate in universal civilisation as an equal partner and maintain dignity, self-sufficiency and originality necessary for such partnership and co-operation, approves this Law on The Principles of State Protection of Ethnic Culture (LRS, 2006).

The importance of ethnic culture is underlined by the law on The Principles of State Protection that determines that the policy of internal affairs should educate national self-sufficiency, the state must assure the protection of Lithuanian ethnic culture, the peculiarity of culture and customs, cherish traditional family, the education system should nurture national self-awareness, respect towards other nations (LRS, 2006). It also indicates that the duty of the state is to retain and cherish national cultural identity, to assure the protection and continuity of the Lithuanian language, to take care of ethnic culture and local traditions, and to protect cultural heritage.

Most of the documents, regulating the life of culture, openly declare that they protect national heritage.

Ethnic culture is not just a mere heritage. The law on The Principles of State Protection of Ethnic Culture defines ethnic culture as the sum total of cultural properties that are passed from generation to generation and constantly renewed, helping to preserve the national identity and consciousness and uniqueness of ethnographic regions (LRS, 2006). There are no doubts that ethnic culture largely consists of a living tradition that is expressed in all spheres of life of nation, which is always changing and adjusting itself to the consciousness and needs of society in a certain period of time.

This investigation was performed during the implementation of the project "Educational Activity of Cultural Centres within the Framework of International Aspect of Community Mobility", funded by the Research Council of Lithuania.

\section{Lithuanian Geopolitical Situation}

Lithuania is a country in the Baltic region, the member of the European Union and NATO. Its geopolitical situation is complicated because it is bound by Belarus to the east and south and Russia (the Kaliningrad region) to the west. Only to the north and west it is surrounded by the EU Member States - Latvia and Poland. Russia and Belarus are governed by dictatorial regimes, which is why Lithuania is a buffer state between democratic and undemocratic regimes. Here the soft security, which is transmitted through culture, is very important. Cooperation between nations takes place regardless of the form of government and especially the state border areas, which combine histories, traditions, natural cross-cultural exchange, and affinities. The citizens of the border areas are influencing each other through cooperation, expanding the cultural and democratic values. Cooperation between cultural centre in the border areas, Lithuanian organizations and local communities are a naturally occurring factor that has a direct influence and very often it "ripens fruits", which 
is more important than the political inter-state relations or the decisions made.

\section{Levels of Institutional Cooperation}

Globalisation is forcing people, societies and organisations to change quickly. According to V. Aramavičiüte (1995), these processes strengthen links with the world as a whole and weaken bonds with local (own) communities. The opposition between globality and locality allows evaluating ongoing processes in two ways: positively and negatively. Intercultural cooperation provides an opportunity to discover other cultures, to get rid of xenophobic and stereotyped attitudes.

Such terms as "cross-cultural", "international", "multicultural" or "of different cultures" occur more frequently in the scientific literature. Sometimes these concepts are understood as synonyms, however they are not exactly identical and they have very distinct differences in different contexts. For example, the concept of "multicultural" refers to the countries, which have different cultural groups, usually as a result of immigration, while "intercultural" defines the differences between the individual states (Houman, 2011, p. 8). The term "intercultural" is often accompanied by other concepts - "communication", "cooperation", and "collaboration". In addition to the fact that these concepts are closely related, they also complement each other. After all, cooperation always starts with communication. Communication is always present in the process of cooperation. The only difference is that "cooperation" raises a common goal, a common objective that requires communication.

According to social psychologist M. Argyle (1991), "cooperation is acting together, in a coordinated way at work, leisure, or in social relationships, in the pursuit of shared goals, the enjoyment of the joint activity, or simply furthering the relationship". As D. Kuliene (2005) explains, cooperation is working together in pursuance of reaching a common goal, whereas communication is "a form of psychological human interaction", inevitable for carrying out any organised work and needed to achieve cooperation.

However, cooperation, whether it is cross-cultural, international or local, always starts with communication. According to A. Houman (2011), intercultural communication occurs when people, creating common meanings, have different cultural perspectives and values. The author claims that this can occur among individuals, groups or even nations. A. Houman (2011) also defines intercultural communication as a cross-cultural cooperation:

"An intercultural encounter would occur when a group of US doctors travel to Brazil and meet with their colleagues in Brazil hospital to exchange their knowledge and techniques. Thus, intercultural communication and cooperation are equally important when working together and aiming to achieve common goals".

There are three levels of international cooperation: macro - when global, multilateral agreements are formed, meso - when regional multilateral agreements are formed and micro - bilateral agreements are settled. This is confirmed by the statement of the Ministry of Culture of the Republic of Lithuania that "Today, international cultural cooperation takes more complex forms of multilateral cooperation, exceeding the limits of conventional initiatives and programmes of national and bilateral cooperation" (The Ministry of Culture).

Cross-cultural cooperation can take place at several levels and it is shown in Figure 1.

Figure 1 demonstrates the vertical cooperation model, when initiative comes from an individual and can evolve into the global level and vice versa. Thus it can be said that this model shows a form of making mutual influence. In this global world, there are many international organisations that announce various projects, 
giving an opportunity for various organisations, members of organisations and individuals to participate in them. On the other hand, individuals and organisations may organise initiatives and projects in pursuance of local, religious and international recognition.

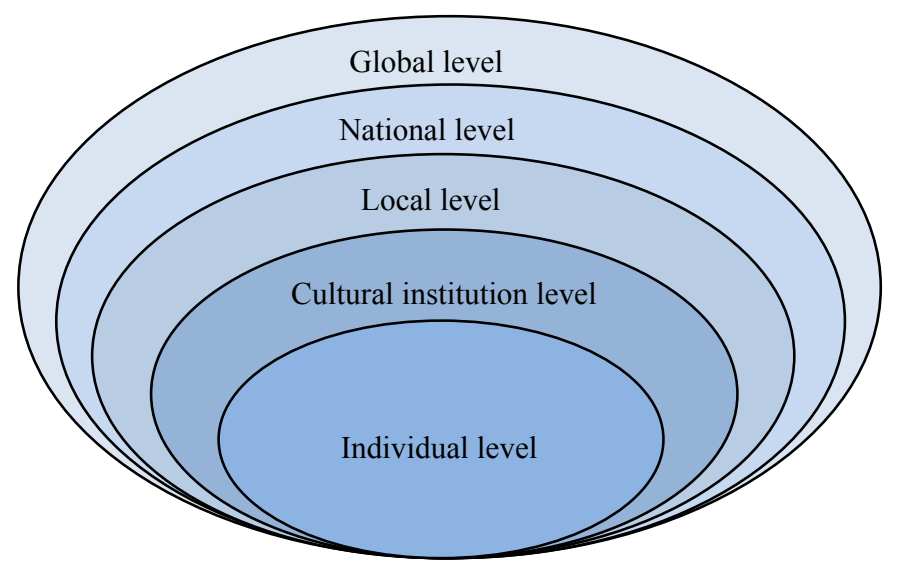

Figure 1. Several levels of cross-cultural cooperation.

In intercultural cooperation, the most essential elements of the cooperation formation process are the levels of cooperation and the roles and responsibilities of these process participants. Figure 2 demonstrates the levels of cooperation.

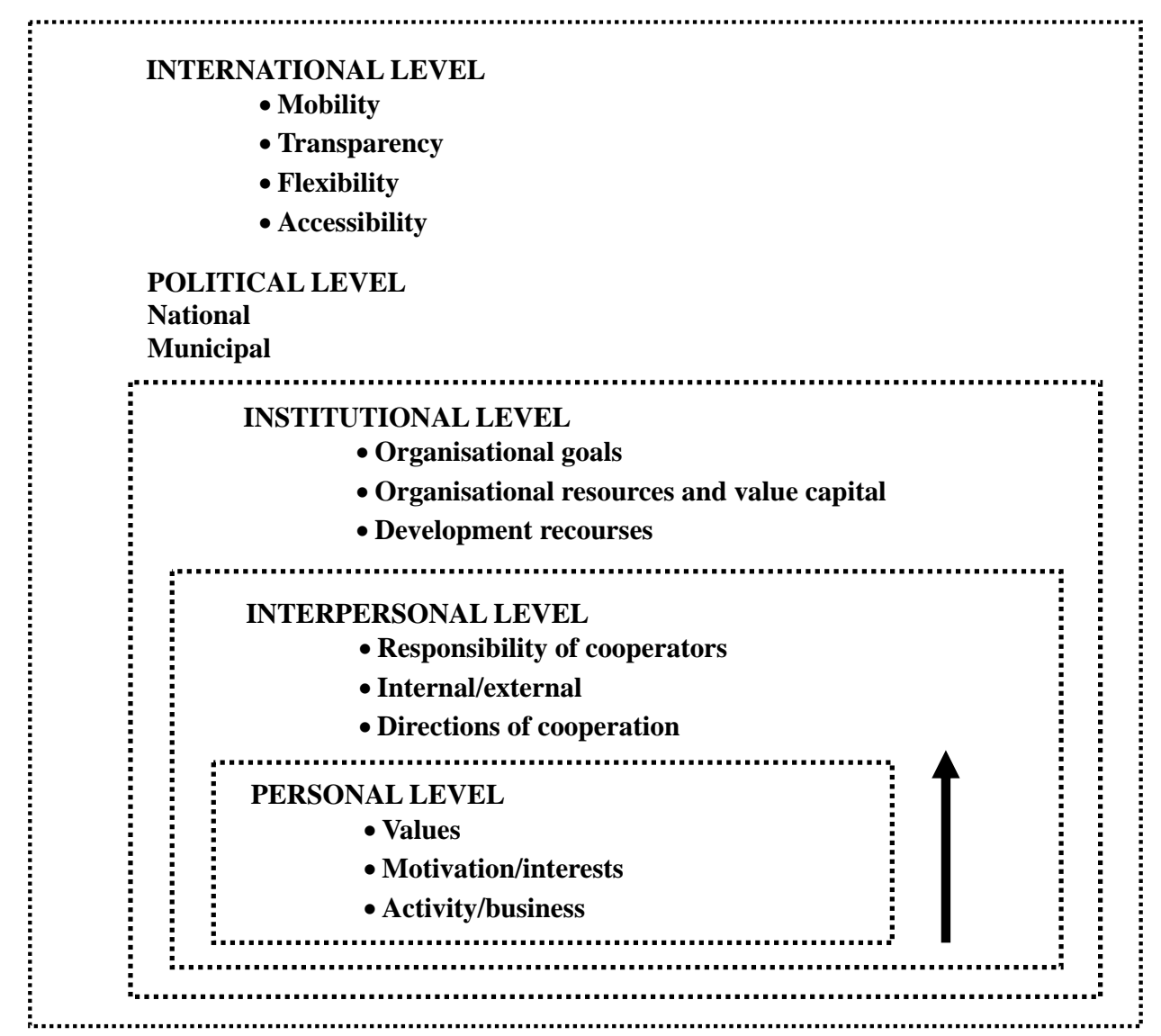

Figure 2. By A. Taylor (2009) Mapping the Field of VET Partnerships / Vocations and Learning, p. 127-151. 
Motivation and interest of person's involvement that stimulate choosing the level of cooperation assert at the personal level. This participation may include different interests, e.g. a community member may seek for a passive participation in the activities of cultural centres, while a cultural centre worker is concerned with a larger number of community members participating in his activities. Values are particularly important at the personal level (trust, relevance, non-indifference, patriotism, and culture loving) in order to continue cooperation and to meet the needs of the member of cultural institutions and community or the user.

Personal communication can develop into the level of interpersonal cooperation. Interpersonal cooperation can be internal institutional (separate individuals or groups or institutions that may influence the work of institution and its change) and external, the institutions of central and local government, other cultural enterprises. Co-operation is defined by agreement; therefore the distribution of responsibilities is very clear.

It will be successful only if the manager passes all three levels of cooperation. At this level, sharing responsibilities is very important. The highest level of cooperation is international, which is characterised by common institutional activities that enable the development and implementation of joint projects. Cultural workers, during the cooperation at the international level gain experience, which allows them to work more creatively and to participate more actively in the reforms of institution.

In summary, it can be argued that, the workers of cultural centres / Lithuanian organisations and managers in intercultural cooperation are involved in one or several levels, subject to their position and initiative. In addition, cooperation at both vertical and horizontal levels may come into play at this level of cooperation. The horizontal level appears when cultural centres cooperate with cultural centres and etc.

\section{Methodology}

Research Instrument. Based on theoretical approaches on cooperation between the community and the cultural centre and intercultural cooperation and cultural issues, two authorized questionnaires were developed: One is for the quantitative survey for the community members, and the other is for the interviews with the managerial personnel of the chosen eight cultural centres. The first standard questionnaire consisted of five blocks of questions. The first block of intercultural cooperation contained three mixed questions. The questionnaire also included five demographic questions on age, gender, nationality, education, and frequency of participation in the activities in a cultural centre. In the second questionnaire, there were also two open questions concerning intercultural cooperation and cooperation between the community and the cultural centre.

Methods. Triangulation was used for the collection of the research data, i.e. even three different methods were used in the research - the survey of experts, interviewing (employees of cultural centres/Lithuanian organizations and visitors of their events, representatives of communities as well as experts of the activities of Lithuanian and Belarusian cultural centres/Lithuanian organizations) and the questionnaire (representatives of Lithuanian, Belarusian and Kaliningrad Oblast communities under analysis). Such a collection of data facilitates to stress the aim of the analyst to interpret the phenomena in those senses that are given by people or organizations under analysis (Kardelis, 2005, p. 271).

This article analyses the cooperation of cultural centres/Lithuanian organizations as well as international intercultural cooperation of cultural centres/Lithuanian organizations.

Data Analysis. Two methods were applied for the analysis of the data. While analysing the answers of community members, the statistics data analysis method was applied, which was performed using software SPSS 15.0 for Windows. The correlations between variables were checked applying Spearmen correlation. The 
difference was estimated statistically of $\mathrm{p}<0,05$ (or $<0,01$ ). The graphical research data were processed using Microsoft Excel 2007.

The research data analysis was performed by applying the descriptive statistics, aiming to generalize data distribution of percentage frequencies as presented in the research data analysis, excluding the respondents' groups depending on social-demographic characteristics.

The qualitative content analysis was applied for the data of interviews with cultural centers' employees (Miles, Huberman, 1994). The qualitative analysis of the content was based on the systemic step performance: 1) identifying the manifest categories, while referring to the 'key' words, 2) dividing the content of categories into subcategories,3) identifying intersecting elements in the category/subcategory contents, and 4) interpret the content data.

Data Gathering. The employed research method was the data collection by performing a survey using a standard questionnaire with closed and open-ended questions for the community members.

The quantitative questionnaire was conducted on August through November of 2012, spreading the questionnaire forms in Kybartai, Pagėgiai, Švenčionys, Lazdijai cultural centers, Sovietsk and Gusev cultural centers as well as in the Lithuanian communities, Pelèsa ir Rimdžiūnai, and schools in Belarus and in Minsk Lithuanian community. The latter was included into the research as a regional Lithuanian community. 1600 questionnaires were shared, out of which 1199 were filled correctly, whereas out of 401 questionnaires 100 were filled incorrectly and 301 questionnaires were not returned. The investigation was more difficult as most of Lithuanians in Kaliningrad region are denationalized and the questionnaire form had to be translated into Russian.

The qualitative research data were gathered in January-March, 2013. Interviews were carried out in order to collect data from the staff of cultural centres.

\section{The Results of the Quantitative Study of Intercultural Cooperation}

The data of the quantitative research about the cooperation of the community and cultural centres/Lithuanian organizations were analysed in the first three levels with the aim to find out the needs of an individual person who takes part in the activities of cultural centres/Lithuanian organizations and intercultural cooperation. Although, originally, the aim was to find out how cooperation takes place among nations inside the country, but the cultural centres/Lithuanian communities under research appeared to be very mono-national, therefore later a more detailed analysis in the paper was refused. Intercultural cooperation in the paper was analysed on the meso-level, i.e. bilateral inter-state level. The research aimed to find out how cultural centres/Lithuanian organizations working in the border region cooperate among themselves as well as on the international level. Analysing the international level, it was noted in the research that it is a mezzo level. That sticks to the regional principle - the Baltic region, with two exceptions, the cultural centres of Kybartai and Pagegiai cooperate on the macro level, i.e. they belong to international networks.

Analysing the data obtained in the research, the primary aim was to ascertain the international level.

Figure 3 provided below presents the opinion of the respondents about the international cooperation.

All the respondents indicated that there is a cooperation going on. The Lithuanian respondents, in comparison to those of Kaliningrad Oblast (91.3\%), are the most critical and only 75.3 per cent indicated that there is intercultural cooperation, whilst more than 90 per cent of the respondents of Belarus and Kaliningrad Oblast (Russia) said that there is cooperation going on. Such an evaluation is not incidental, as the Lithuanian 
respondents are more active and carry out cooperation with many countries in the EU, therefore they are more demanding and critical, and they think that the cooperation is not such as they want it to be. The cooperation of the Lithuanian communities in Belarus and Kaliningrad is limited to the EU countries, and therefore they highly value the cooperation with art organizations of Lithuania and Poland.

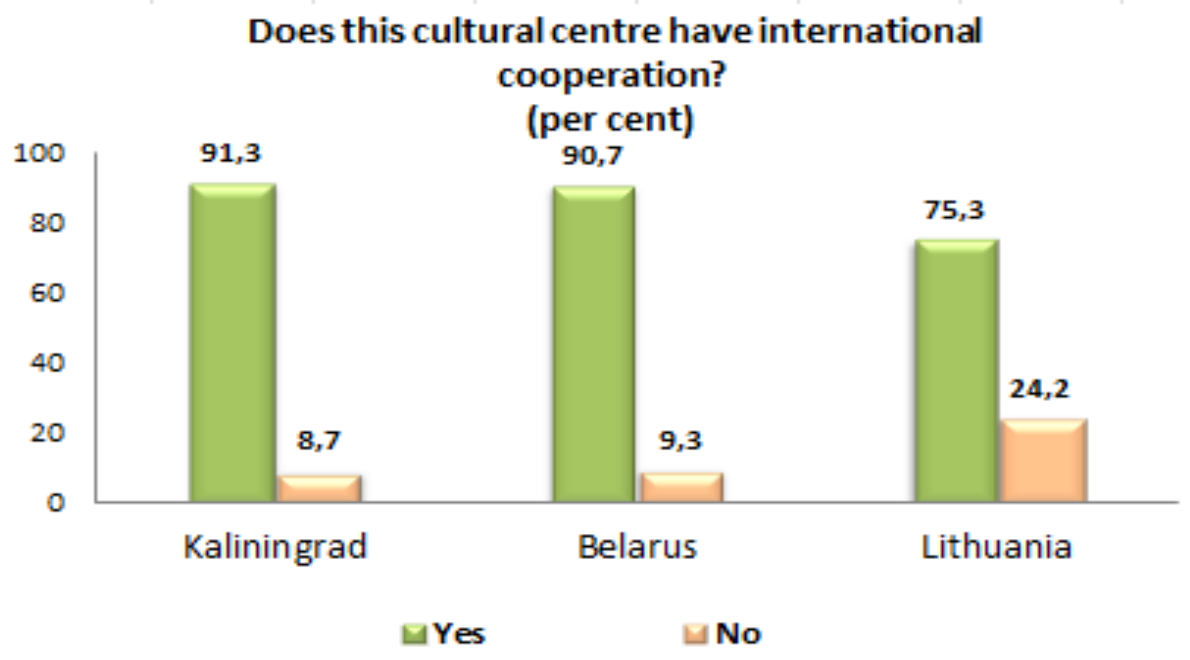

Figure3. Intercultural cooperation of the cultural centre. N=973.

The below given graph gives the analysis of what intercultural cooperation gives to the respondents personally. The respondents could choose three answers that suited most.

\section{What does intercultural cooperation give to you personally? (per cent)}

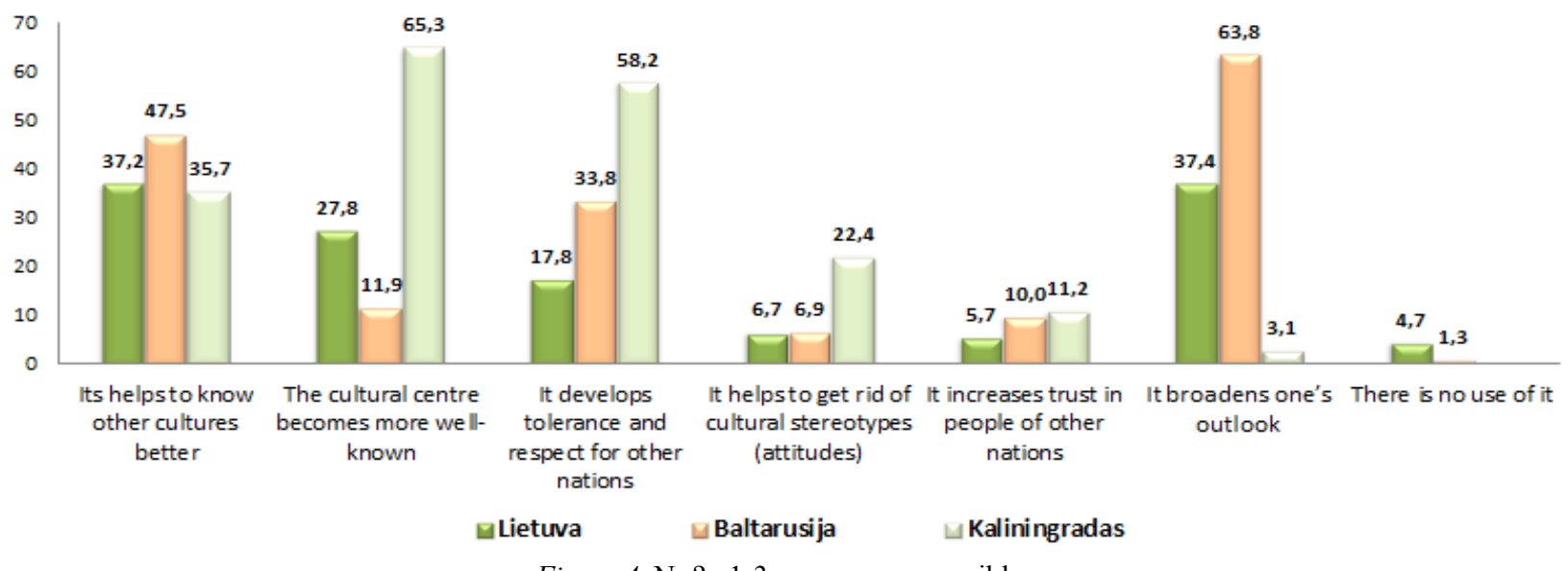

Figure 4. N=? , 1-3 answers are possible.

As it is evident from the diagram, 37.4 per cent of Lithuanian and 63.8 per cent of Belarusian respondents indicated that intercultural cooperation allows them to expand their outlook and, as compared to other answers chosen by these respondents, these were the variants that were chosen most often, and the percentage is bigger by a few hundredths of percentage points (37.4 per cent) than the indication of Lithuanians that it helps to get to know other cultures and people of other nationalities. The respondents of Kaliningrad Oblast (Russia) indicated most of all (65.3 per cent) that it increased the popularity of the cultural centre, and 58.2 per cent indicated that it stimulated tolerance and respect for people of other nationalities. Only 3.1 per cent of the respondents 
thought that it broadened their outlook. The respondents in Belarus (1.3 per cent) and Lithuania (4.7 per cent) thought that there was no use of it.

The respondents of different states differently evaluated the benefit obtained from the cooperation of cultural centres/Lithuanian organizations. The respondents of Lithuania and Belarus, having more possibilities to cooperate more widely, chose the statement that it helps to know other cultures. Such a choice might have been determined also by the immense emigration from Lithuania. The Lithuanians in Kaliningrad are more denationalized and link their future more with Russia, therefore it is more important for them to increase the popularity of the cultural organization, as they participate in national events and seek to gain the financial support from the state.

Figure 5 shows how intercultural cooperation is carried out.

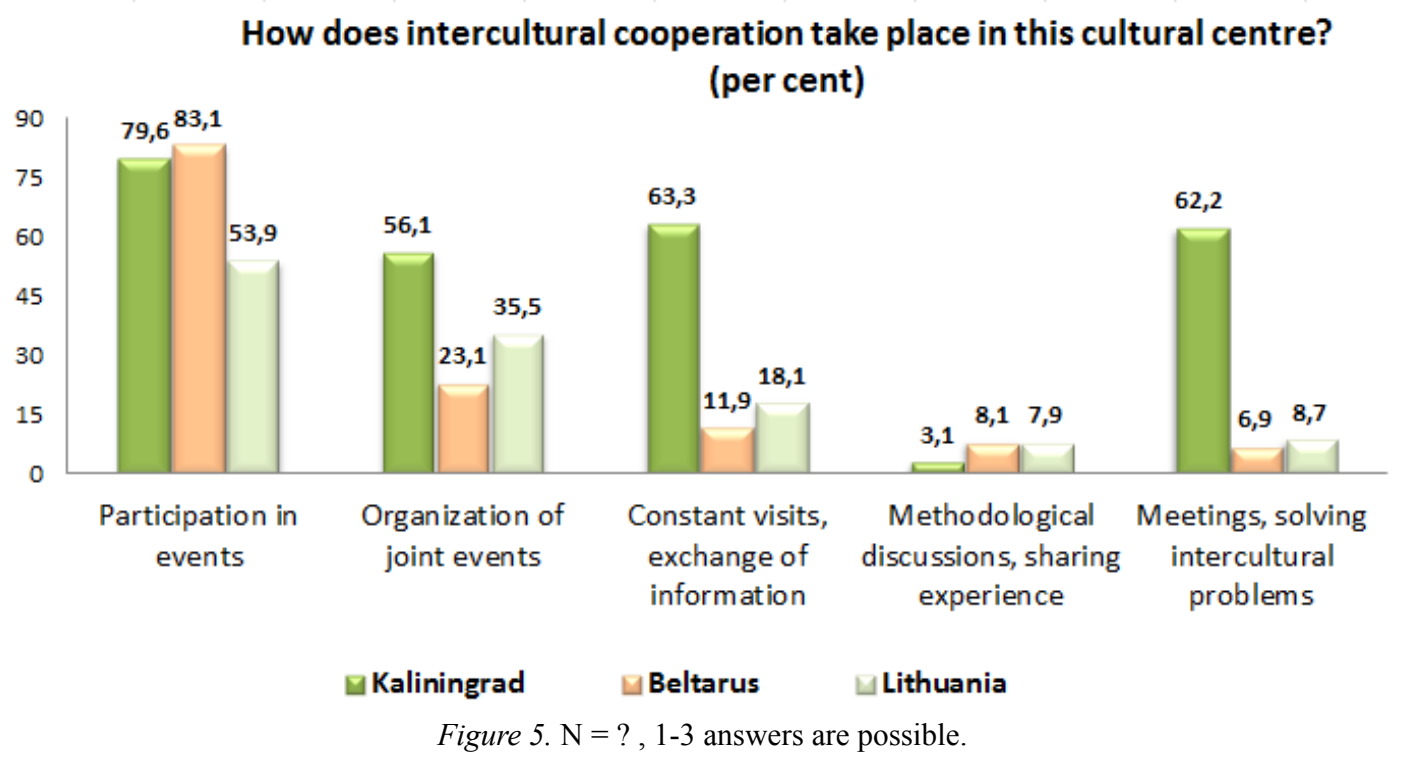

The respondents could choose more than one variant, so the respondents in Kaliningrad Oblast chose the participation in events most of all (79.6 per cent), and the constant visits and the exchange of information were in the second place (63.3 per cent). All the respondents in Lithuania (53.9 per cent), Belarus ( 83.1 per cent) and Kaliningrad Oblast (79.6 per cent) indicated that taking part in events is the most popular form of intercultural cooperation. The Lithuanian respondents (35.5 per cent) and Belarus (23.1 per cent) indicated that intercultural cooperation takes place in organizing intercultural events; however, the respondents in Kaliningrad Oblast put it in the third place according to importance. They can make a conclusion that the most important form of intercultural cooperation is participation in events, and after it there is the organization of common events, though this is not a prevailing tendency. All the respondents unanimously agreed that the most unpopular form of intercultural cooperation includes methodological discussions when sharing their own experience.

Intercultural cooperation was the highest level of cooperation, as it is determined not only by inter-institutional agreements, but also by international ones. It can be regarded as micro-level, as there are bilateral agreements.

The research aimed at finding out about the cooperation among the cultural centres/Lithuanian organizations and the local communities. The diagram below gives the answers chosen by the respondents.

All the respondents ( 90.2 per cent in Lithuania, in Belarus — 398.0 per cent, and in Kaliningrad Oblast — 
76.3 per cent) think that they carry out cooperation. The respondents of Kaliningrad ( 76.3 per cent) think that they do have cooperation, and 46.7 per cent think on the contrary. It is the largest number of respondents that indicated that the cultural centre/Lithuanian organization did not cooperate with the community. It can be related to the fact that there were many young respondents among all the respondents, and they did not take part in the activities of the community or were not fully involved in them. The respondents of Lithuania and Belarus (more than 80 per cent) stated that there is a cooperation going on.

\section{Does this cultural centre have cooperation with the local community's centre? (per cent)}

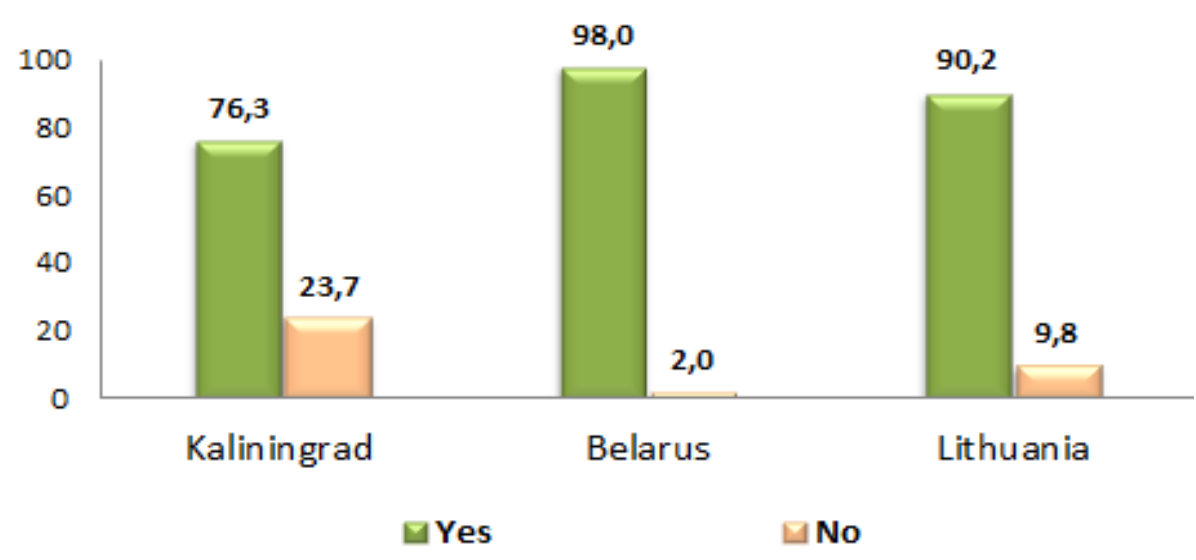

Figure 6. $\mathrm{N}=1073$.

The forms of cooperation are shown in the diagram below.

What are the forms of cooperation between the cultural centre and the community? (per cent)

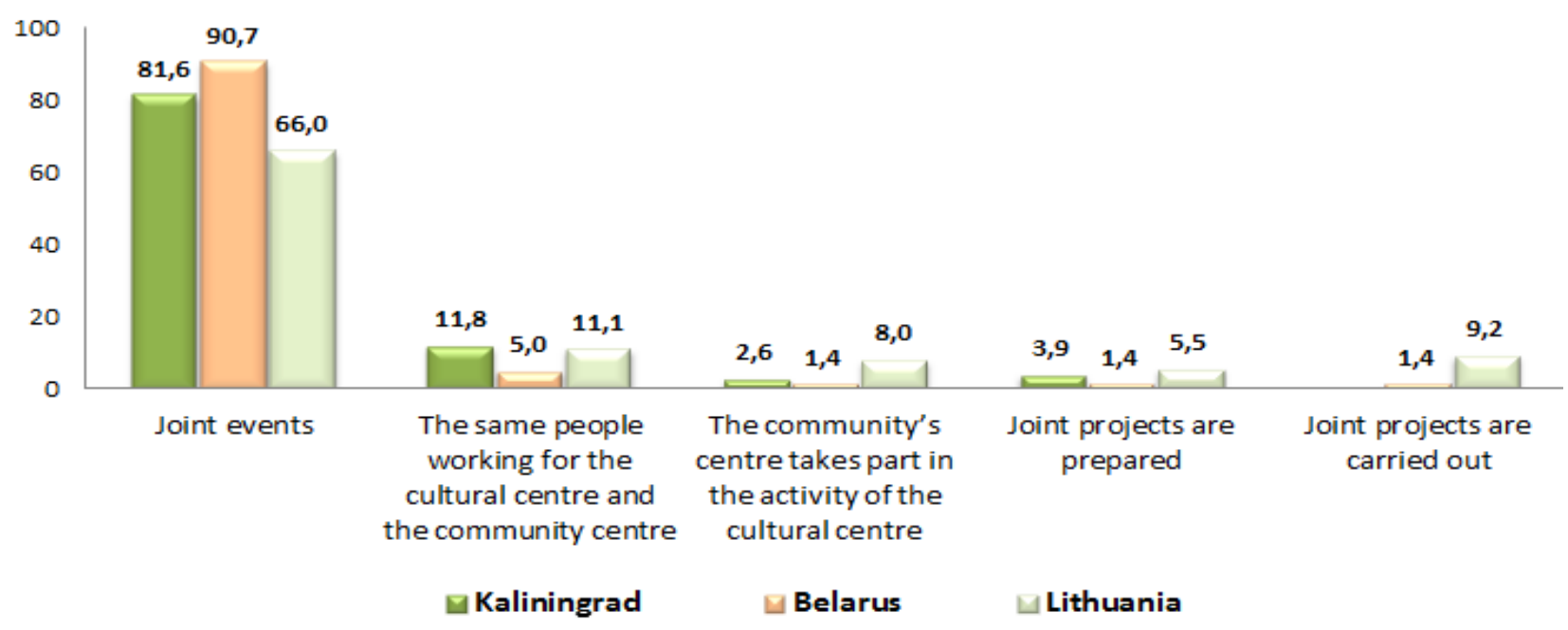

Figure 7. $\mathrm{N}=889$.

The respondents of all the three groups under research said that there are common events organized (in Lithuania - 66 per cent, in Belarus - 90.7 per cent, and in Kaliningrad Oblast -81.6 per cent). The Lithuanians said that the same people are working both at the cultural centre and at the community centre (11.1 
per cent) and are carrying out common projects (9.2 per cent). The respondents of Kaliningrad Oblast also underlined that the same people are working both at the cultural centre and the community centre (11.8 per cent), while in Belarus only five per cent thought that the same people are working at both of the institutions. However, there is the same tendency in all the three groups under research - there are common events of the community centre and the cultural centre, and both of the organizations use the same human resources.

Thus, the results of the quantitative study showed that cultural centers / Lithuanian organisations carry out vertical cooperation from the bottom (from an individual or cultural organisation) to the global level, i.e. macro cooperation, as well as horizontal cooperation, when cooperation is happening among the organisations that are at the same level, such as one cultural centre cooperates with another cultural centre.

The qualitative research also revealed the levels of cooperation and the roles and responsibilities of these process participants.

In order to evaluate the cooperation of the cultural centres and the Lithuanian communities under research in the border regions of Kaliningrad Oblast and Belarus with educational institutions and local communities as well as peculiarities of intercultural cooperation, the informants were asked four open-ended questions about it. The answers to these questions allowed to thoroughly define the nature and volume of cooperation in the mentioned cultural organizations.

The informants from the cultural centres functioning in Lithuania, when answering the question "Cooperation with educational institutions: Is it going on or could it go on? What are its aims?" and defined in detail in the cooperation that is being developed first of all with local schools. "School helps us, we also help school. We have a very intense cooperation". Other educational institutions that the cultural centres have cooperation with were also mentioned: "We cooperate with kindergartens, schools and the additional education centre. We try to organize events, festivals and attract as many people as possible. We try to involve as many institutions as possible". Therefore, there is a close connection felt between the local schools and cultural centres that is best reflected by this statement of an informant from Pagegiai:

"We do our best and we think that we need that cooperation very much. However, I do not know if the school needs us. The school has a lot of activities, but they are not evident, while the activities of the cultural centre are much more seen. We advertise our events more. We need school children in order to achieve better results, for example, carry out a quiz and other events".

The informants noted that there is a cooperation in organizing joint events and festivals (We cooperate with other educational institutions, we help one another, arrange festivals together, various events.), preparing projects (We cooperate a lot with the primary school, we organize practical works together.) or inviting the kids (We cooperate with educational institutions. Earlier, we could not "share" talented children. Talented kids attend the music school, so we want them also to have performances in the cultural centre. So we adjust our agenda to their timetable, if they come to the centre. Right now we are "sharing" the kids"). It is interesting to note that according to some informants, there is no rivalry between schools and the centres when organizing their activities (We are happy to see that various ensembles in subdivisions closely cooperate with schools when preparing the events, carrying out projects, so such cooperation is very tight, there is no rivalry. We already have a tradition that at least a couple of events per year are common events-these are usually traditional festivals), while others do mention competition (The cultural centre organizes events that are important for this region. We cooperate with schools including the events into their function, which they perform very well. We 
know more about such events and it is easier for us to include them in the agenda. There is a competition between us and the educational institutions, but we try to attract the youth - those young people who have nothing to do - by our professional attitude).

The informants described the cooperation with local communities also in the similar way, mentioning the organization of common events and activity preparing and implementing projects (We have a close relation with the community. They help us to organize events. "We are like a fist" or "We arrange festivals, events, projects together with other communities"), stressing the educational benefit of such cooperation. Such cooperation gives a lot to people, it broadens their outlook. Here it should be noted that the position of cultural centres under research is to look at the local communities as at the partners because of limited human resources (for example, We have a cooperation with the local community, we help each other, as our town is very small), and not as rivals, still such an overlapping of activities and the lack of human resources seem to be problematic, as well, especially at the cultural centre of Pagegiai. The communities are not competitors to the cultural centres. We cooperate a lot, we share our experience voluntarily or our employees work in the communities free of charge, which is, of course, not good, but it is just a momentary culture, as there is no continuation of it. We cooperate really a lot, even three chairpersons of the communities are my employees, and all of us are members of the council of the communities. Often we, when organizing the events, write down on the documents that the organizers are both institutions. Or people from the community centre come to us to discuss some issues, when preparing events. Sometimes there are disagreements when my people work as chairmen of the communities, because they spend all their time there and do not come to their "real" work for three days and more. But, of course, it is for the better, as they are entitled as "counselors" in the articles of our organization. We are often called friends.

The informants from Švenčionys cultural centre were distinguished from other cultural centres by a wide scope of their cooperation: They mentioned the cooperation with other cultural clubs, local museums, libraries, Youth centre, the boarding house, the join-stock company "Svirka". Therefore, this cultural centre is distinguished by its networking as well as other social activities. Also, only the employees of Švenčionys and Lazdijai cultural centres mentioned that they had cooperation with the local government. There are good relations with the local government, the municipal administration. "We organize events together" (the informant from Lazdijai cultural centre) or "We have a cooperation with the neighborhood, local administration and the municipality of Švenčionys" (the informant from Švenčionys cultural centre). It is evident that all the rest cultural centres have more cooperation partners that they simply did not mention during the interview.

The experts are also of a similar opinion. Expert 1 stated that "the cultural centre working actively and purposefully, that is able to provide professional services, models the life of the local community, cultural fashion, attitudes, etc. In the regional areas, these centres function as national philharmonic societies, theatres, etc. Thanks to them, professional art reaches people; moreover, they initiate various activities of members of the community, bring them all for a joint activity, cherish the local traditions, trade them, and create them. Finally, the cultural centre is a place where all the members of the community may gather together and simply talk, meet, find friends and satisfy their social needs.

Expert 2 added that if it were otherwise, the cultural centres would lose their point, and the communities could not carry out all-rounded and good cultural activity without cultural centres. Only here they should specify the term of the community. The community here is used in the broader sense - the local residents (of 
a village, settlement and neighborhood). Today legal acts legitimated a perverted concept of a community, in their opinion. Their legitimation registering them as non-governmental organizations (a community must consist of at least five members) formed a situation when there are several communities functioning in one little town.

Expert 3 said that in cultural centres/Lithuanian organizations, local people have a possibility to develop their outlook, they are taught tolerance and have a chance "get rid" of many "bugaboos" that sometimes are created on purpose, and sometimes not.

Generalizing the cooperation of cultural centres/Lithuanian organizations both during the interview with the representatives of the centres/organizations, and with the experts, it was underlined that the cooperation is close and without it no development of the society (the community) is possible, and cultural centres/Lithuanian organizations would lose their function.

The answers of the informants and experts indicate that the Lithuanian cultural centres actively develop intercultural cooperation. Kybartai cultural centre, according to what was said by the informants, has a cooperation with Poland, Russia (Kaliningrad Oblast), Germany, and Bulgaria. Most often the cooperation is implemented through participation in events or carrying out joint projects, although it is affected by the shortage of funds (Often we do not go there, as the costs of travel and visas are quite high).

The informants from Lazdijai cultural centre pointed out that the Polish and Belarusian were among the most active partners they cooperated with when organizing events (Most often we cooperate with the Lithuanians in Punsk. We invite bands from neighboring countries to come to festivals and events. We already had guests from Poland and Belarus) and in project activities (There have been projects prepared with Poland, we also prepared a project with Belarus together with the Foreign Ministry of Lithuania to enable the cultural bands' exchange visits), also Kaliningrad Oblast and Latvia were mentioned (International cooperation is most evident when organizing the Border Fiesta where we receive ensembles from Latvia, Grodno and Sejny, Punsk, Lukov towns in Poland, children folk ensembles of Poland and Kaliningrad. The festival is devoted for the neighbouring countries. Sometimes their traditional events gradually become traditional events here, as well, such as the festival of the Assumption in Sejny or Punsk...). Therefore, the traditional event Border Fiesta is an important centre of attraction in order to start friendship relations and develop them.

Pagegiai cultural centre, according to the informants, also has cooperation with cultural organizations in Kaliningrad Oblast and Poland (their artist collectives and Lithuanian communities) as well as an NGO in Sweden. Still, as one informant said, "We are so close to Kaliningrad Oblast, and we make no use of such a situation...". The similar was said by the informants from Švenčionys cultural centres about the international relations with the ensembles from Belarus, Latvia and Poland (We have cooperation with Latvians and other ensembles, their leaders, with Latvia, Belarus...).

The informants talked little about the plans how to develop their international cooperation, for instance, the informant from Lazdijai said that the relations with Latvia are a little down now: with Bauska, Jurmala. The situation is complicated with Belarus, as we have no direct relationship. The international cooperation lacks consistency and purposefulness, and the informant from Švenčionys stressed the lack of financial means our aim is to form a circle for cooperation, but it is subject to finances as well as to the cultural policy. We have plans to develop our cooperation with Latvia.

The statements of the informants from Russian and Belarusian border regions also witness about the close cooperation between cultural centres and the Lithuanian organizations with schools. "There is a cooperation 
developed with schools, kindergartens, when there are festivals, we come as managers, we help to choose and teach dances, children then come to our centres and join our ensembles to dance. I had some groups in schools, and pupils leant to dance waltz. We organize city festivals, then we also cooperate with schools, kindergartens, we share responsibility" or "School and community are all in one. The community is a cultural union to cherish Lithuanian culture. Local authorities fully finance our activities" (the informant from Rimdžiūnai). There is also a tight relation with the local Lithuanian community, as well, for example, the informant from Belarus Lithuanian school said "The cultural centre cooperates with the local community centre, on the other hand, there are so few of us, Lithuanians, here, and we try to stick together, we celebrate all festivals, both Lithuanian and Belarusian ones, we organize and we invite all the communities to our events". While, the informant from Gusev cultural centre first of all indicated the non-governmental public organizations as their partners for cooperation: "Public enterprises are our partners, as well, for instance, the club of veterans or elderly disabled people. Although, we ourselves offer more events for the latter club". Similar things were also said by the informants from the border region of Kaliningrad Oblast.

Differently from employees working at cultural centres in Lithuania, the informants in Belarus and Kaliningrad border regions mentioned also the cooperation with Lithuanian politicians. "Each year pupils of our school go the President's residence" (the informant from Belarus) or "I still can feel the interest from the Lithuanian consulate because they do take care of what has been achieved. The Attaché of Culture takes part in all our events... they visit us often, observe our classes. They bring the Lithuanian press" (the informant from Russia).

Intercultural cooperation is also a very important part of the activity of cultural organizations that took part in the research; however it was described differently by people from Belarusian and Kaliningrad Oblast border regions. As it was said by the informant from Belarus, there is cooperation with other ethnic communities. For example, there are two important schools in this centre-Lithuanian and Belarusian. There is a very active cooperation. As they take part in many festivals. They even understand that they have two motherlands: Belarus and Lithuania. That, of course, depends upon their age, but they think that they have two motherlands. If there is an anniversary or other important date of a famous Lithuanian writer or other famous figure, we always organize commemorative events and we invite people of other nationalities, as well. One informant from Belarus also mentioned their plans to develop international cooperation with the World Lithuanian Community ("We will try to become part of the World Lithuanian Community. We plan to take an active part in the cooperation with Polish, Armenians, and Latvians"), while several other informants said that the visa regime makes intercultural cooperation more difficult ("It is difficult to cooperate with Lithuania, as visa regime forms a big obstacle").

While the informants from the Russian cultural centres and Lithuanian communities mentioned the cooperation of the ensembles and organizers of cultural events from other countries, first of all, from Lithuania, and from Poland. "We have cooperation with Kybartai cultural centre, with the Polishpeople - they are just $20 \mathrm{~km}$ away. We exchange the performances of our ensembles as well as our knowledge" or "There is intercultural cooperation going on. It consists of keeping contacts, relations, sharing our experience. It is interesting to see how other cultures live. It is both official and unofficial cooperation. We often cooperate on the professional level".

The informants were also asked what importance the intercultural cooperation of their organizations has for the local residents. Their answers underlined the benefit of international cooperation that is primarily 
expressed by the enhancement of enthusiasm of the residents. The informant from Kybartai cultural centre said: "We benefit, because German ensembles visit us, and then a more intense cooperation starts. The Germans invite us to seminars, and they want to develop our cooperation. Their community is open to all nations". The informant from Pagegiai cultural centre mentioned, different to what was said by the previous one, that it is their community, and not their organization, that gets most of benefits. "It has an immense meaning, because our residents actively cooperate with the people of Soviest town". Another informant from Kybartai stressed the tourism development as also a positive aspect of intercultural cooperation. "When ensembles start their cooperation, families also make friends, which expands the intercultural cooperation and allows to develop tourism".

The informants from all the four cultural centres of Lithuania said that the proof of the importance of international cooperation is a bigger motivation, although all of them were talking about their own artist ensembles. For example, the informant from Pagegiai said that such an activity is immensely important as people, after encountering with another culture, come back as on wings, and they get down on their feet only after some time. Or according to the informant from Lazdijai cultural centre, the cooperation, for instance, with Punsk is useful, because we feel we are colleagues, we discuss, help one another and we are happy about that. And it already is life together, devotion to Lithuanianism, its culture. The similar was said also by the informant from Gusev cultural centre: "It depends upon the person's background, social status or age. Children communicate very easily and quickly make friends".

Another meaningful aspect of international cooperation as deciphered in the statements of the informants was that of education, i.e. the broadening of one's outlook, because people learn more and thus understand other cultures better. The informant from Lazdijai cultural centre put it in this way: People have a chance to come and see people of other temperament. For instance, the Belarusian are totally different from us when they are on the stage. They are like a wind, they dance and sing wildly. It is good to see what kind of people there might be. The informant from Kybartai underlined also the feeling of pride in one's own culture: People get to know other cultures and they see and compare cultures. And the feeling of prestige and pride is very important for any community. It is the information of the town and country given to a community, and after some time you find out that there is already a Polish coming to visit Kybartai.

The valuable aspect of international cooperation is the education of tolerance and it appeared to be important for the informant from Pagegiai cultural centre: It is a huge contribution to a more unanimous community achieved through different events and festivals. People are really tolerant and friendly, they are ready to help one another. It teaches to respect our culture, to cherish it, and it also teaches tolerance, respect towards elderly people. The informant from Švenčionys also mentioned tolerance and respect for otherness that are educated in a multi-cultural community: Intercultural cooperation brings a lot of benefit. Švenčionys region is mixed from the national pint of view; therefore neighbours have to find a way to live next to one another. They also have many relatives in Belarus.

The informants from cultural organizations at the border regions in Kaliningrad Oblast also mentioned the influence of intercultural cooperation upon education of tolerance. For instance, all of us get knowledge about another culture, which brings up respect for it. People become better, because they get something new, and something good. If we see that there is something good in another culture, and we do not have that, we will be trying to take it as an example of goodness. Not only knowledge is increased - respect increases, as well. We try to nurture respect. 
Generalizing the statements of the informants about the cooperation of their cultural organizations, it is evident that it forms a significant part of their activity, partially determining the success of many events they organize or artistic activities they perform. For instance, the cooperation with local schools allows the cultural centres to use the human resources of the educational institutions as well as arrange some events together; besides, the pupils of the schools are also members of artists' ensembles of the cultural centres. Naturally, competition emerges out of such a situation.

Another important field of the Lithuanian cultural centres under research is the relations with the local communities that are most of all expressed by the organization of joint events or work in the projects. On one hand, it helps to solve the problem of the lack of human resources,and on the other hand, there appears a situation of the "leaking off" of the resources of the local community.

It could be assumed that the development of cooperation with higher educational institutions, for example, providing places of internship for students, or with other organizations (social care, NGO, etc.) would allow to develop the fields of activities and influence.

Speaking about the statements of the informants from cultural organizations in the border territories of Russia and Belarus on their cooperation with the local educational institutions, they can notice two situations. In Belarus, the Lithuania cultural centres or the Lithuanian emigrant communities are symbiotically conglutinated with the local Lithuanian schools, thus, the issues of the lack human resources, the membership of children attending artistic schools as well as those of premises or the attraction of the local Lithuanians are solved. While, in Kaliningrad Oblast, the situation is different: Here, in line with the Russian laws, the active local national autonomies, although they can receive the state support, are dispersed, not unanimous, the activities they organize are not popular among the local Lithuanians, so they encounter the problems of the lack of premises, human resources and other problems. Partially, it was felt that some of the informants did not want to cooperate, which also was the reason of the scarce volume of the quantitative research.

The experts also noticed that the cultural centres/Lithuanian organizations are very active in intercultural cooperation.

Expert 1 indicated: The cultural centres carry out a very active intercultural cooperation, starting with the national or local projects that are devoted for the cognition or publicity of various cultures or subcultures living nearby. These are various projects of national minorities, artist collectives of national minorities, projects of food culture heritage, youth projects, etc. The cultural centres carry out an active cooperation, and as a result of it, people of various countries and different cultures visit Lithuania. At the same time, the artists' ensembles, individual creators, and artists with their exhibitions of our country often take part in international projects in other countries where they present cultural peculiarities and traditions of Lithuania. International and intercultural communication and cooperation are one of the most remarkable factors of the development of tolerance and democracy.

Expert 2 said that the opened borders expanded cooperation. There are many international events going on, cultural-social projects are implemented with foreign partners, etc. Of course, such an activity positively contributes to the development of tolerance and democracy.

Expert 3 noted that there are joint festivals and cognitive informative events.

Generalizing the results of the quantitative and qualitative research, it can be stated that the benefit of the international cooperation is defined in three aspects: personal (broadening of one's outlook and development of values), organizational (motivation of the members and improvement of ensembles) and social (encouragement 
of enthusiasm of the local residents, increase of tolerance, and development of tourism).

The cultural organizations that took part in the research actively develop their intercultural cooperation that is mostly revealed through cultural exchange, organization of joint events and project activities. It became known that the cultural centres in the border regions of Lithuania keep active international relations with cultural organizations from the neighbouring countries - Poland, Belarus, Latvia and Kaliningrad Oblast. On the other hand, the cultural organizations at the border regions of Belarus and Kaliningrad Oblast most often cooperate among themselves and with Lithuania.

Summing up the ideas of informants about intercultural cooperation, it can be argued that it is going on at the micro and meso levels.

Table 1 demonstrates the cooperation partners of project participants.

Table 1

The Cooperation Partners of Project Participants

\begin{tabular}{|l|l|l|}
\hline Lithuanian Cultural Organisations & Lithuanian organisations in Belarus & $\begin{array}{l}\text { Lithuanian organisations in the } \\
\text { Kaliningrad Region (Russia) }\end{array}$ \\
\hline $\begin{array}{l}\text { Belarus, the Kalningrado region (Russia), Poland, } \\
\text { Latvia, Sweden, Bulgaria, Germany }\end{array}$ & Lithuania, Poland & Lithuania, Poland \\
\hline
\end{tabular}

As it can be seen from the provided data, the cultural centres in the area of Lithuanian border with Belarus and the Kaliningrad region (Russia) are much more active. One of the reasons may be the legal status of cultural centres - they are state centres, financed from municipal budgets, whereas another reason is their active work in order to raise the cultural centre qualification category, which can guarantee stable organisational activity and the engagement of young professionals and participants in centre activities. In addition, the cultural institution that is influenced by market economy conditions and depends on the level of political solutions can often be threatened with restructuring, optimisation and other options. Only the optimal cooperation of cultural organisation at all levels may minimize the above-mentioned threats and guarantee stable, creative, diverse and multi-level activities.

\section{Conclusion}

Intercultural cooperation is working together to reach a common goal. Intercultural cooperation takes place inside the country between different nations, which can be macro, meso, and micro. It depends on the scale of intercultural cooperation at the micro international level: cooperation between two nations of the state, whereas macro are the international networks that already have international network agreements. Cooperation may be horizontal and vertical. Horizontal cooperation includes the cooperation of the same level organisations, and vertical cooperation is multi-levelled from personal and global-international.

Intercultural cooperation of cultural centres /Lithuanian organisations is also seen in the horizontal levelcultural centres / Lithuanian organisations and local Lithuanian communities cooperate with each other or with other organisations that are at the same level. This was confirmed by both qualitative and quantitative research.

The intercultural level of cultural centres/ Lithuanian organisations is also seen at micro, and meso levels. The study has not approved the macro level of intercultural cooperation. Usually cultural centres cooperate at the macro level which is manifested by bilateral agreements. Only one Lithuanian Cultural Centre strives to get in the macro level of cooperation to join the World Lithuanian Community.

The forms of intercultural cooperation are different, but generally it is organising common events or 
participation in festivals and competitions and more rarely planning joint projects. The benefits of intercultural cooperation were stressed by all interviewed persons and experts. It helps to increase tolerance, eliminate cultural stereotypes, reduce xenophobia and expand horizon. Educational and motivational aspects were also indicated.

\section{References}

Argyle M. (1991). Psychologia stosunków międzyludzkich, PWN, Warszawa.

Armanavičiūtè V. (1995). Vertybès kaip gyvenimo prasmės pamatas. Acta pedagogica Vilnensia, T.

Becktord, J. (2002). Stakeholder participation. Part tour: Methods, tolls and techniques (pp.288-302).London:Routledge. Retrieved from http://web.ebscohost.com/bsi/

Finlay, I. (1998). Stakeholders, consensus, participation and democracy, in I. Finlay, S. Niven, S. Young (Ed.). Changing Vocational Education and Training: an international comparative perspective (pp.3-18). London: Routledge.

Houman A., S. et al. (2011). Intercultural Communication: A New Approach to International Relations and Global Challenges. Retrieved from http://books.google.lt/books?id=zkK0YqB4cfQC\&printsec=frontcover\&hl=lt\#v=snippet\&q=intercultural\%20communicatio $\mathrm{n} \% 20$ defin*\&f=false

Kardelis, K. (2005). Moksliniu tyrimu metodologija ir metodai. Šiauliai: Liucilijus.

Leliūgienė I., Sadauskas J. (2011). Bendruomenès sampratos traktuotės ir tipologija, Socialiniu mokslu studijos, 3(4), $1281-1297$.

Lietuvos Respublikos Seimas. (2004). Lietuvos Respublikos Kultūros centru ịstatymas 2004 m. liepos 15 d. Nr. IX-2395. Valstybès žinios: Nr. 120-4435.

Taylor A. (2009). Mapping the Field of VET Partnerships. Vocations and Learning, 127-151. 